\title{
Research on the Tactics of Cultivating Business English Talents under the Background of "One Belt And One Road" Strategy
}

\author{
Li Xiaoni \\ Humanities and International Education College, Xi'an Peihua University; Xi’an, China \\ 442563364@qq.com
}

Keywords: One Belt And One Road, business English talents, Training Status, strategy research

\begin{abstract}
Since President Xi Jinping proposed the strategic design of jointly building the "Silk Road Economic Belt" and the "21st Century Maritime Silk Road Economic Belt", China has closer ties with the world economy. The influence, radiation and driving force of China in the international arena have been greatly enhanced. Judging from the implementation of bilateral or multilateral trade, and investment standards between China and the countries along the "One Belt And One Road", there is a great shortage of excellent business English talents. In the process of promoting the "One Belt And One Road" strategy, it is urgent to cultivate versatile business English talents with innovative ability. Based on the demand of talents, this paper analyzes the current situation of business English talent training, and proposes that Chinese colleges and universities should cultivate versatile professional talents who are proficient in English, business knowledge and skills as well as innovative ability.
\end{abstract}

\section{Introduction}

In 2013, Chinese President Xi Jinping put forward the strategic design and idea of jointly building the Silk Road Economic Belt and the 21st century Maritime Silk Road Economic Belt .The convening of the 2017 One Belt And One Road summit in Beijing marks that this strategic concept has been put forward, implemented and promoted in an all-round way. China has entered a new era of reform, opening-up and economic development. With development of Society and economy, education and talent cultivation are more important. Business English talents in China face more and higher requirements in application-oriented universities. From our country and other nations along One Belt And One Road, the national technical regulations and standards are implemented on a bilateral or multilateral trade and investment. We are lack of professional and technical talents and translators. The curriculum setting, professional teaching, extracurricular practices, especially English translation, are far from the business professional knowledge and professional skills they should possess, which directly affects the accuracy of China's policy communication information.

Therefore, One Belt And One Road's strategic promotion not only needs support from the silk road fund and Asia Infrastructure Bank, establishment and adjustment of related business English majors and the development of related professional and technical talents are also important prerequisites(1). Business English aims to cultivate high-quality interdisciplinary talents who are good at commanding of English, business and communication through cross-cultural communication and cross-border transactions, which to a large extent meets the needs of "One Belt and One Road" talents. In the process of promoting the "One Belt and One Road" strategy, business English professionals should be constantly trained. Based on the demand for talents, this paper proposes the training path for education business English talents in Chinese universities, and improves education and talent training quality and promotes the healthy development of China's economy and society.

\section{Current situation of business English talents cultivation in China}

At present, under the background of "One Belt And One Road" initiative, higher requirements 
are put forward for the cultivation of business English talents in China. Due to the current social environment and training mode, there are still several problems in the cultivation of business English talents. By analyzing the current talent training mode and combining the specific and practical teaching mode, the author thinks some problems mainly lie in the following aspects.

\subsection{The deficient curriculum and weak practical teaching}

Business English branches out from common English because of the need to cultivate practical talents. However, from a comprehensive view, it is not difficult to find that the teaching of business English majors in colleges and universities is not reasonable. More theoretical and systematic knowledge is taken as the teaching key point, and the communicative nature of business courses is completely ignored. The vocational course system is not obvious, and the comprehensiveness is not good. In addition, the practicality of business English determines the importance of practicalness in the teaching process. However, in most business English classes, teachers often make a simple explanation of the textbook knowledge in a scripted manner, and practical case analysis is rare. In the meanwhile, the main problems in business English teaching are unclear teaching objectives, and single and stereotyped examination method. In the teaching process, teachers do not take the cultivation of high-quality professional business talents as the teaching goal, but spoon-feed some traditional teaching methods and concepts to students. At the same time, in the process of assessment, the paper score is only regarded as the only standard of students' comprehensive ability, and the assessment of business English ability is totally ignored.

\subsection{The teaching mode is single and the teaching method is boring}

Compared with ordinary college English, professional business English study not only sets a higher standard for students' language proficiency, but also requires students to understand complex professional terms, business practices and related business operation procedures in the professional language environment(2). But throughout the business English teaching classroom in colleges and universities, business English education workers generally use the teaching plan for many years with single teaching mode and the textbooks is the only reference material. The application range of computer projection technology is very small, and some old teachers seldom explore the use of PPT. In the spring tide of education reform, even though computer technology and so on went into business English class, most of them were only limited to a simple outline of the class on the projector, the teacher still analyzed the textbook with students according to the old methods and the key points of the examination. Over time, students will be tired of learning business English and lose interest in learning, which makes it difficult to motivate students and makes business English teaching difficult.

\subsection{Students have poor basic skills}

The English translation ability of Chinese business English majors is relatively poor, mainly reflected in the lack of specialized vocabulary, Chinese translation is serious in the process of translation. Students do not have a solid grasp of the necessary translation theories and skills, so they will not be able to distinguish between the structure of the English and Chinese language differences, and lack of understanding of English social background and culture. The phenomenon of mistranslation and misinterpretation is very serious(3). Lack of interpretation training and practice in the training process, students' interpretation level is seriously lower than translation ability. Besides effective classroom study, they seldom participate in translation exercises and practices outside the classroom.

\subsection{Unreasonable course Settings and separation of English and business}

At present, the curriculum of business English major in most universities focuses on the basic knowledge of English listening, speaking, reading, writing and translating in the first two or three semesters. It is not until the second year of college that business English related courses are offered, such as international trade practice and introduction to business. As a result, English is separated from business. In the early stage of learning English, the students know nothing about business, but 
when the students focus on business, they gradually forget the basic knowledge of English. How to combine English with business organically in the process of business English teaching is a problem that needs to be solved by professional business English teachers.

\subsection{The content of cultivation is unrealistic and the practicality is weak}

The textbook is the carrier of education reform content and belief, and the premise of the reform of teaching content. However, there are few professional textbooks for the cultivation of business talents, and most of them are professional mixed books. The content of the books is single, the form is old. Although various departments are trying their best to solve the problem of teaching materials, there are not many authoritative books in China, so it is inevitable that there are few choices. In addition, education infrastructure in many places is not in place at present, resulting in weak market price links in teaching. The content of the training is not specific, and the effect of the training is not satisfactory. As a result, the trained talents are difficult to adapt to the needs of the society.

\subsection{Teachers deficiency}

Business English teaching is not only a skill teaching, and also language teaching, therefore, the demand for business English teachers is higher and higher at the present stage. Business English teachers are required not only to have basic business English knowledge and relevant business skills related to teaching, but also to have sufficient teaching experience and ability. Teachers can improve students' ability to deal with problems by simulating all possible situations and accumulate experience in class. At present, most colleges and universities in China do not pay enough attention to business English major, and there is a shortage of teachers. Moreover, a large number of teaching tasks also hinder and restrict the further improvement and further study of teachers, and seriously aggravate the contradiction between teaching tasks and teacher development, which not only delays the cultivation of students, but also delays the construction of teachers.

\section{Training strategies of business English talents}

\subsection{Set diversified and multi-level curriculum system}

In order to adapt to the development of the times and the demand for business English talents, the curriculum setting should be diversified and multi-level. Only in this way can we meet the development needs of students, improve their comprehensive abilities and expand their multi-level and diversified horizons.In the teaching process, on the basis of the effective combination of English knowledge and business knowledge, the knowledge of various disciplines can be infiltrated and integrated with each other. The effective cultivation of students' language skills, business practice links and humanistic quality can be strengthened on the basis of fully understanding the essential ability of business English talents.For example, In the teaching process of international business negotiation, after the teaching material is finished, the teacher can assign students to arrange a business negotiation by themselves. The class is divided into 4 to 6 groups, each of the two groups shall be the negotiating parties. In such practical negotiation, the students collect many relevant materials by themselves which not only exercises the students' language expression ability, but also stimulates their interpersonal skills. Meanwhile, polite and orderly negotiation can also effectively improve the students' humanistic quality.

\subsection{Reforming model and teaching method}

The developing foreign trade economy needs the reform of business English teaching mode and teaching method in colleges and universities. Combining the traditional spoon-feeding teaching with the modern education concept, we take the essence and discard the dross. First of all, in the course of teaching, teachers can simulate the real environment of business English according to the unit. In the interaction activities between teachers and students and between students and students, students should play a specific role in the context of business English environment. It is not only conducive to the cultivation of students' ability of thinking, but also to the effective improvement of their ability of perspective-taking and practical work in the business environment(4). In addition, 
teachers should consciously take students as the subject of the classroom, and position themselves as the guide of the classroom. In this teaching model, teachers design classroom contents on the premise of fully understanding the basic situation of students, and effectively group the class students, so as to cultivate students' learning enthusiasm and creative thinking in group discussions. Finally, classic cases are selected to cultivate students' positive thinking ability, communication ability and analytical skills under the guidance of mature cases, and students are required to express in English, which is also the training of students' language expression ability.

\subsection{Optimize the curriculum setting and build the teaching system of production, education and research}

In recent years, with the deepening of the reform of business English teaching in colleges and universities, certain achievements have been made in teaching methods, curriculum system and curriculum setting. Therefore, while deepening the reform, we should promote the current advanced experience, such as adding professional knowledge courses on the basis of traditional skills and language knowledge in the current business English curriculum. While most college courses have different names, the basic framework is pretty much the same. In addition, in the process of imparting basic knowledge, we need to deepen the connection with large enterprises and build internship opportunities with sufficient exercise space for students. And seeing business English during the internship as an important part of professional learning, so that students can flexibly use the basic knowledge they have learned. Finally, it is necessary to constantly optimize business English courses, and give full play to the advantages of business English teaching by improving the reasonableness of the theoretical courses of business English. To cultivate the innovative ability and professional skills of business English talents, practical teaching must be emphasized. Only through practice can students be tested whether they can apply what they have learned in specific jobs and improve their comprehensive ability in the process of practice(5).The cultivation of innovative business English talents in colleges and universities should be based on the core idea of training innovative ability in practical training, and adhere to the fundamental approach of combining production, teaching and research, so as to form a practical teaching system that is in line with the theoretical teaching in the classroom.

\subsection{Strengthen the construction of teaching staff}

The current situation of shortage of business English teachers cannot be improved in a short term. Therefore, we need to start from strengthening the construction of the teaching team to cultivate high-level business English teachers with sufficient basic knowledge and business skills, as well as sufficient teaching experience and ability. First of all, business English teachers must have a solid English foundation. On the premise that they have certain business trade experience and knowledge, they also need to have sufficient economic theory foundation and be able to skillfully use multimedia and network teaching.As a comprehensive discipline, business English covers a wide range of areas. Therefore, we should encourage teachers and employees to learn e-commerce, marketing, business management and financial insurance knowledge. Therefore, we should encourage teachers and employees to learn knowledge of e-commerce, marketing, enterprise management and financial insurance, and integrate the above knowledge into the teaching class, so that students can be fully trained in the class and be cultivated to the high-level talents with excellent quality.

\subsection{University and enterprise cooperation training}

The resources of both universities and enterprises are integrated to carry out multi-directional and multi-level cooperation, providing off-campus practice places for the cultivation of innovative business English talents in colleges and universities. The school should assign students to these off-campus training bases for practical training in combination with production and learning. School-enterprise cooperation makes up for the insufficiency of practical teaching resources in the university. Students can take advantage of the internship opportunity to learn by doing, and complete the transition from classroom to work. Students go deeply into the front line of enterprise 
production and management, and also they can follow the factory and enterprise instructors to learn on site. During this period, students can actually understand foreign trade company departments and post setting and master the business processes and workflow of foreign trade enterprise. From this experience they can acquire practical experience in the operation of specialized courses such as business negotiation, business correspondence and telecommunications, documentary practice, customs declaration and inspection. Thus they will form a specific perceptual knowledge to the upcoming work, and have a clear impression on foreign trade practitioners. In the real work environment, students face many challenges of the role, identity and status transformation, and inevitably encounter various difficulties, which is undoubtedly a test process for students' practice and innovation ability. To solve problems successfully, students must motivate their own subjective initiative, and learn how to make a correct judgment according to the actual situation, and use the knowledge and skills to determine the corresponding solutions and strategies, so as to display their talent and accumulate valuable work experience.

\subsection{Improve the comprehensive quality of business English talents}

In view of the needs of export-oriented enterprises for the other abilities of business English talents, in combination with the current situation of regional export-oriented economic development, it is widely expected to improve the comprehensive quality of versatile business English talents. Enterprises may be able to relax the academic requirements for business English talents, but the requirements for comprehensive quality will only be higher and higher. Good professional ethics, professional dedication, teamwork ability, innovation ability will be valued by enterprises. Therefore, the colleges and universities should integrate the quality of education into the various links of business English talent cultivation, and strive to cultivate high-quality versatile business English talents. For all the changes that may occur in the future work, the colleges and universities should also pay attention to the cultivation of students' sustainable learning ability, so that they can not only get on the job quickly, but also be able to face the changes as the situation changes and learn and adapt to the changes actively.

\section{Acknowledgements}

This paper is the periodical achievement of Shaanxi Province Social Science Fund "Research on the cultivation of cross-cultural communication ability of minor languages in western Asia under the background of One Belt And One Road” with the Project number of 2018Q20.

\section{References}

[1] Xia Jinlong. Application of multimedia teaching in business English Correspondence and telecommunications teaching in Vocational colleges [J]. Hua Zhang, 2010 (27): 106-108.

[2] Research group of Baoding College of Higher Finance. Strategic Conception of Outward Oriented Economic Development in Hebei Province [J]. Financial Teaching and Research, 2002 (5).

[3] Xie Dingsheng, Long Xiaogang. Germany "dual system" Vocational Education Teacher Training Model and its Enlightenment [J].Journal of Hubei Radio and Television University, 2010(9): 18-20.

[4] Zhang Bingzhao. Practical Exploration of the "order-type" Talent Training Mode of School-enterprise Cooperation [J]. Higher Education Exploration, 2005(4): 72-74.

[5] He Xuelian. Research on the Cultivation of Business English Talents for Regional Economy [J]. Journal of changchun university, 2012 (4): 464-468. 